\title{
NON-AGENDA
}

With the view of causing an increase to take place in the mass of national wealth, or with a view to increase of the means either of subsistence or enjoyment, without some special reason, the general rule is, that nothing ought to be done or attempted by government. The motto, or watchword of government, on these occasions, ought to be - Be quiet... Whatever measures, therefore, cannot be justified as exceptions to that rule, may be considered as non-agenda on the part of government.

- Jeremy Bentham (c.1801)

\section{Do We Know Federal Treasury Overspends on Undergraduates?}

\section{Jonathan Pincus}

$\mathrm{I}$

deally, decisions about changes in the levels of public spending, or about other changes in public policies, should be made on the basis of estimates of their

likely economic consequences, preferably in a general-equilibrium model (for example, Heckman, 1999). This article asks whether that kind of evidence has been used to inform decisions about public policy in higher education in Australia. The focus here is on the inferences, for economic efficiency, that can be drawn from evidence on rates of return to investment in higher education. The conclusion is that we should reserve judgment about whether the Treasury is spending too much.

The tuition costs of most Australian undergraduates are met by grants to the public universities made by Federal government from its available pool of public funds, arising from taxes and charges. Since 1996, these university grants have risen more slowly than university cost indexes. Such a funding squeeze is in keeping with the proposals of the National Commission of Audit (1996), that government take 'efficiency dividends' from publicly funded bodies.

A policy change improves economic efficiency if it produces more benefits than costs (including opportunity or option costs). The excess of benefits over costs can conveniently be presented as a rate of return, when investment of public

Jonathan Pincus is George Gollin Professor of Economics at The University of Adelaide. 
and private resources are involved, and the benefits extend over a number of years. There is a standard set of techniques, deriving originally from the field of public finance, for making estimates of the costs and benefits that arise from policy changes.

These do not seem to have been applied systematically in Australia. Instead, inferences about desirable policy changes have been made on other grounds. Australian policy recommendations in higher education seem to have been based on a combination of theory and fairly casual empiricism, in which average rates of return figure prominently. For example, according to the Australian Financial Review editorial on 27 May 1997, undergraduate teaching grants to universities are middle-class welfare, paid at the expense of other taxpayers, many of whom are earning lower incomes than earned by graduates. In support of its case for a radical reduction in the grants, even their complete abolition, the $A F R$ editorial cited the claim that graduates on average earned a high rate of return on their educational investments.

More generally the lines of argument followed are like these: Public monies should be diverted from universities because the rates of return to university education are lower than those in some other forms of publicly-supported education (Dockery, Norris and Stromback, 1998) or other public projects (the implicit assumption being that public revenue will not be spent on projects with even lower returns than university education). Or, one can point to deficiencies in institutional design or to defects in the policy framework facing universities, particularly the restrictions on the operations of the price system (for example, Miller and Pincus, 1998). Since the incentive system is wrong, the results must be inefficient; since the results include some level of public spending, it must be too high, whatever its current level. (This conclusion is supported by the assertion that universities, their staff and students, have been effective in converting their interests into political pressure.) Or, that public spending of this type is only justified by references to externalities, market failures, or unintended consequences of other public policies (since university students are undeserving of public assistance, being a privileged class). As externalities cannot be measured, and some are negative, better count them as negligible. Capital markets are not really a problem (for example, Heckman, 1999 suggested that no one in the US who could gain by education beyond high school is prevented by liquidity constraints; see also Fane, 1988; contrast Chapman, 1997). As to offsetting the deleterious effects of other public policies, although it is true that the progressive income tax system discriminates against college education, the effects are surely too small to worry about.

In the Australian policy context, quantitative evidence for policy seems typically to have been based almost entirely on estimates of the rate of return to extra years of education (or to different educational choices) - there is scant quantitative evidence for most of the other arguments listed above. The rate of return to investment in higher education is calculated as the discount rate that would equalise the present value of the life-time earning stream flowing from 14 
years of schooling (say), and the earnings stream from 15 years of education; or the comparison could be between the incomes earned by those with a high-school certificate only and those with a degree. The rate is net of educational outlays incurred. When this rate is calculated on earnings gross of tax, and when no distinction is made between private costs and costs met from the public purse, like tuition grants and income support for students, including forgone earnings, then it is called 'the social rate of return to education'.

Ideally, the social rate should also include adjustments for externalities and the like. It is widely thought that it is the most appropriate measure to use for policy purposes. If it is higher than some appropriate 'hurdle' rate reflecting the opportunity cost of investment resources, then the activity that generated the social rate has added to and not subtracted from economic efficiency. In addition, a 'private' rate of return to education can be calculated, from the point of view of the students and their private funders (for example, family). Incomes are then taken net of taxes, and only private costs considered. Finally, the rate of return to 'Treasury' can be estimated, with extra taxes as the benefit and public educational outlays as the cost.

There are three kinds of dangers in relying on the rate of return to education, for policy purposes. First, they are usually calculated as average rates. For policy purposes, what are needed are marginal rates of return, to compare with some standard.

The second difficulty is that the calculation of a rate of return to education or its interpretation requires assumptions about some of the very magnitudes that are at issue in the policy debate: the size of the (marginal) externality generated by higher education; the separate contributions of ability and education to earnings; the speed with which markets adjust to changes in educational policy; the utility or disutility of work and study. These are considered later.

When relying solely or mostly on rates of return to education of the kind described above, the third danger is that some costs of public finance are ignored. Raising the legal minimum of years of education to, say, 15, could increase the amount of higher education taken by Australians, and generate a rate of return to education. In calculating the net benefit, for purposes of policy evaluation it could be reasonable to ignore the deadweight costs of the taxes required to fund the enforcement of the law, as being of a second-order of magnitude. The most significant of the recent policy changes in higher education, however, have consisted of attempts to change the incentives and constraints facing individual and institutional decision-makers, by means that generated first order consequences for public finance. A specific example, discussed later, were the large rises made in the 1996 Federal budget in the Australian form of graduate tax called HECS. This budget change should be evaluated as a differential change in sources of public revenue, as well as for its effects on educational choices of students. The standard calculation of the social rate of return to education ignores the public finance aspect entirely. 
The last point can be generalised - each policy will generate different consequences. This indicates the need of a policy-specific rather than an allpurpose rate of return. What is required are estimates of the marginal social rate of return to investment, with respect to a specific policy change.

\section{Averages and Margins}

A Treasury rate of return can be calculated from estimates of the receipts of HECS payments and of tax attributed to higher education, less Treasury outlays attributed to higher education. Under current policy settings, the average rate of return to the Treasury from public expenditure on higher education is very 'high' (Pincus, 1998; Borland et al, 2000). Clearly, a high number for the Treasury's average rate of return does not justify the current level, a decrease nor an increase in Treasury 'investment'. The calculation attributes to the public expenditures on higher education all of the extra taxes collected from the graduates (from the portion of their income attributed to higher education, as discussed later). That is to say, the estimate of a Treasury or public-sector rate of return assumes that, absent public subsidies, no one would have attended university (see Harrison, 1997 and his reference to Blaug, 1970).

Relying on the average rate of return would not prove a fatal deficiency in some circumstances. For example, if the average social rate of return to investment in higher education were below the hurdle rate, it would be reasonable to assume that the marginal rate of return would also be less than the hurdle rate. However, the estimates of the average social rates of return have tended to range well above the usual benchmark of around 5 or 6 per cent (for example, 16.5 per cent in Borland et al, 2000), and so that comparison would not immediately justify reductions in public spending.

As mentioned above, the high numbers estimated for private rate of return have been used to support an argument for reductions in government grants. The argument is strongest if we adopt the extreme assumption, opposite to that mentioned in dismissing the usefulness of the Treasury rate of return to its higher education spending, namely, that reductions in public subsidies would make no difference to university attendance. Absent that assumption, we have to guess how much the margin is below the average.

In the Industry Commission's Submission to the Review of Higher Education Financing and Policy is found a policy-relevant use of private rates of return to higher education, relating to that assumption. The Commission reported calculations, collected in the table below, of the impact on private rates of return for some professional occupations, under different fee regimes, on the assumption of no change in any economic variable in response to changes in fee regimes. As the variations in estimated private rates of return were small (as you read across the table), the Commission went on to argue that changes in fee policy would 
have small effects on enrolment patterns and, therefore, the efficiency consequences of fee policy would likewise be small.'

Table: Private Internal Rates of Return to Higher Education

\begin{tabular}{|c|c|c|c|c|c|c|c|c|c|}
\hline \multirow[b]{3}{*}{ Course } & \multirow[b]{3}{*}{$\begin{array}{l}\text { Length } \\
\text { in years }\end{array}$} & \multirow{3}{*}{$\begin{array}{c}\text { No fees } \\
(\%)\end{array}$} & \multirow{2}{*}{\multicolumn{2}{|c|}{$\begin{array}{l}\text { HECS system } \\
(\%)\end{array}$}} & \multicolumn{5}{|c|}{ Extent of cost recovery (\%) } \\
\hline & & & & & 40 & 50 & 75 & 100 & 100 \\
\hline & & & $\begin{array}{l}\$ 2,478 \\
\text { fee }\end{array}$ & $\begin{array}{l}\text { Differential } \\
\text { fees }\end{array}$ & \multicolumn{4}{|c|}{$\begin{array}{l}\text { Deferred with income-contingent } \\
\text { repayments }\end{array}$} & $\begin{array}{c}\text { Up-front } \\
\text { fees }\end{array}$ \\
\hline Architecture & 5 & 8.9 & 8.4 & 7.8 & 7.9 & 7.8 & 7.4 & 7.1 & 4.9 \\
\hline Computing & 3 & 23.3 & 21.7 & 20.8 & 21.0 & 20.7 & 20.2 & 19.7 & 12.8 \\
\hline Education & 4 & 11.9 & 10.8 & 10.4 & 10.3 & 10.1 & 9.6 & 9.2 & 6.6 \\
\hline Engineering & 4 & 17.4 & 16.2 & 15.6 & 15.3 & 15.1 & 14.8 & 14.6 & 9.4 \\
\hline Law & 4 & 18.1 & 17.2 & 16.3 & 16.9 & 16.7 & 16.4 & 15.8 & 11.7 \\
\hline Nursing & 3 & 13.6 & 12.3 & 11.5 & 11.2 & 10.9 & 10.2 & 9.3 & 5.5 \\
\hline Science & 3 & 22.3 & 20.7 & 19.7 & 19.4 & 19.1 & 18.6 & 18.5 & 11.9 \\
\hline
\end{tabular}

Notes: Attributes all income differential by level of education to education. Income is after tax. Average for males and females

Source: Industry Commission (1997:Appendix 4)

This inference would be more secure if there were no serious reservations about the accuracy of the estimates of the average rates of return. Continuing for now to focus on the distinction between margins and averages, notice that tuition is a small component of the total costs of undergraduate education; forgone earnings are much larger. Therefore, relatively small changes in the portion of tuition cost that is passed on to the student would be expected to reduce the student's private rate of return by a very small amount. If that rate were initially at the kind of levels shown in the first column of the Table, the effect would be 'infra-marginal'. However, the story could well be different for marginal students, those with low expected differentials of graduate over non-graduate earnings and, therefore, with low private rates of return. A relatively small rise in tuition charges could reduce expected rates of return of those, marginal, students below an acceptable level, and dissuade them from enrolling. We need information about the size distribution of rates of return, not the average of that distribution, to estimate the size of the effects.

1 For New Zealand, Maani (1997) estimated that hypothetical changes in fee and grant regimes made little difference to the private attractiveness of higher education. Maani's cautious policy conclusion was that '...investments in post-compulsory secondary and tertiary education were worthwhile' (p. 189; see also 126ff and 185). For Australian data on the (lack of) effects of HECS changes, see Andrews (1999). 
Inference of the type just discussed would be more secure if there were no serious reservations about the accuracy of the estimates of the rates of return, matter to which we now turn.

\section{Rents and Quasi-Rents}

Central to the calculations are the income differences attributed to increases in the levels of education completed. In discussing what policy-relevant information they (or their rate of return derivatives) contain, the focus will be on rents or quasi-rents arising from two separate sources - market disequilibrium and ability (see Ehrenberg and Smith, 1997; Heckman, 1999).

Because the income differentials are derived from age-earnings profiles at a point of time (for example, in the year of the census), they incorporate quasi-rents. Say that the estimated return to higher education is high in comparison with some standard. The cause may be a recent shift in the pattern of demand for educated workers, driving up their incomes. Workers or students will be drawn into the high-paying occupation, at a rate that depends on the size of the pool of suitable people; on how long they expect the attractive income premium to last; how costly the education; how specific the skill; and the like. Employers, and intermediate and final consumers, will seek cheaper substitutes. Therefore, even if the demand shift proved permanent, the 'excessive' skill premium would tend to erode, at a speed that depends on the relevant elasticities. Evidence derived from census income profiles, and the like, may be seriously misleading. A 'high' estimated value for the rate of return to education, in these circumstances, may have no significance for general policies on the funding of undergraduate education. (See Butlin, 1975; Heckman, Lochner and Taber, 1999.)

Taking this argument to the extreme, if income were all that mattered to graduates from education, we would expect in equilibrium that the graduates' private rates of return would be high enough to justify the financial and other sacrifices they make and the considerable and virtually-uninsurable risks they take (Hope and Miller, 1988). Rates of return that have been appropriately adjusted to reflect equilibrium outcomes (or paths to those outcomes) would then be 'high' only if the usual economic processes that squeeze rents were operating weakly or not at all: if, for example, tertiary places were considerably constrained by quota or other forms of non-price rationing; or if capital or liquidity constraints significantly discouraged university-ready students from undertaking higher education. The policy conclusions that flow from these causes are, naturally enough, quite different from those consequential upon excessive public subsidies.

There are other, mostly unmeasured influences on the rate of return to higher education. For example, if it is more fun to study at university than to undertake a trade apprenticeship, and if university study brings life-long non-financial benefits, as seems to be the case, then university students would accept a lower rate of financial return from university. 
The income differential earned by those with higher education may in part be the consequence of persistent differences in earning ability which were present when the person applied to and was admitted to university. In consequence, it is common to attribute to higher education less than all the income differential earned by graduates and, in the absence of reliable evidence, an 80 per cent attribution has become conventional. That such an arbitrary adjustment is made should suggest caution about policy implications being drawn from estimates of rates of return.

Only if these factors - riskiness; quotas on places; private liquidity constraints; disutility of study — were considered on balance to have a minor effect on the equilibrium rate of return, would it seem reasonable to infer from a 'high' social or private rate of return to higher education (and from that alone) that the correct policy could be to reduce the private rate of return by reducing the fiscal support for undergraduate education, as was suggested in the Australian Financial Review (1997), and as was done in 1996.

\section{Rate of Return Attributable to a Policy}

Consider the policy relevance of estimates of the 'social rate of return to extra time spent in undergraduate education'. 2 Students are increasingly undertaking 'double degree' studies in preference for 'single degree' studies, and staying longer at university. Presumably, the private rate of return they expect is sufficient to compensate them for the extra study effort, foregone earnings and HECS charges, and so on. Assume the private rate is 'high' but, to focus the discussion, also assume that it translates into a 'social rate of return' of five per cent; and that five per cent is the appropriate hurdle rate for policy purposes.

This equality between the hurdle rate and the social rate of return does not mean that the best policy, then, is to do nothing. Governments have available a range of policies to influence student decisions about length of study undertaken (for example, limit the HECS loan arrangements to four years of study, or double the HECS charge for years in excess of four, or re-regulate the universities' decisions about the number of commencing students admitted). Each policy will generate a different stream of endogenous reactions from students, parents, employers, universities, and so on; each will have a different consequence for the amount of investment, public plus private. Each, therefore, will generate a different rate of return - what was earlier called a 'policy-specific rate of return'. Some policy-specific rates of return could be negative, and some positive; of the positive, some could be below and some above the estimated 'social rate of return to higher education' of five per cent. Any policy that yields a policy-specific rate of return that exceeds the hurdle rate should be implemented, regardless of the socalled 'social rate of return' to extra time spent in undergraduate education.

2 Maani (1997) provides extensive calculations for New Zealand along these lines. 


\section{Public Finance}

The policy implication from the Industry Commission's evidence, cited above, was that a tougher fee regime was desirable, presumably because of the saving in public spending and the consequent reduction in the excess burden of taxation. Why not make a direct estimate, of a kind common in public finance economics, of the tax savings and of their economic value? Even when based on relatively crude methods, such calculations seem at least as relevant to public policy as the estimates of rates of return of the kind discussed earlier.

The most significant policy changes in higher education in the last decade were made in 1996. These were the increases in and differentiation among degrees of the HECS charges, the stiffening in the terms of repayment and the pause in growth in operating grants to institutions. In commenting here on this package of changes, rises in HECS payments and repayment rates are treated as involving a switch in the mix of public revenues.

In 1996, the government raised what it calls 'HECS charges' by a weighted average of 70 per cent, corresponding to a rise of about $\$ 730 \mathrm{~m}$ in the steady state. $^{3}$ Increases in HECS charges are not simply increases in the 'prices' that students pay, with economic effects like those of any price increase. A commercial charge or price would generate income to the suppliers of the services being paid for. If it were a competitive industry, the price increase would be the result of market forces, not a government directive (Clotfelter, 1996). Australian public universities, however, are not permitted to charge fees for the vast majority of undergraduates. In these circumstances, if the extra HECS revenue had been added to university grants, then some of it, possibly most, would have been used to pay increases in university salaries; some to permit university staff to undertake more self-directed professional activity other than teaching; and some, possibly a minor amount, would have been used in non-price competition, some manifest as increases in the levels of teaching services to students.

In fact, the grants to universities, who supply the services consumed by students, were reduced in the 1996 budget. That is, for students as a whole there was no quid pro quo - the extra student payments went to reduce the budgetary 'black hole'. That is, they had tax-like characteristics, in that government was collecting monopoly profit, what usefully can be called quasi-taxes (just as was the case with many of what were formerly public enterprises). Associated with this form of government revenue-raising, there is an excess burden to be estimated.

Since 1989, the government-imposed tuition charges can be paid 'up-front' or deferred. If paid up-front, then the excess burden of public revenue is that associated with the exercise of monopoly or market power. If a student defers

3 DETYA (1999:Table 2.12) estimates a $\$ 656 \mathrm{~m}$ rise in HECS liabilities between 1995 96 and 1999-2000. Changes in HECS fees in intermediate budgets, and changes in enrolment numbers and patterns should explain the difference. 
payment, and most do, their mode of HECS payment has more tax-like qualities. A capitalised borrowing charge at the rate of 33 per cent of the tuition fee is added to the tuition charge; thenceforth, a zero real interest rate is charged. (In government literature, those who make up-front payment are misleadingly portrayed as having received a 25 per cent discount.) The debt so incurred is repaid at rates that depend on the taxable income of the student or graduate.

In $1995-96$, about $\$ 220 \mathrm{~m}$ was received by government by way of incomecontingent repayments. Recently, amounts of over $\$ 600 \mathrm{~m}$ in income-contingent repayments have been collected through the tax system, projected to rise to over $\$ 780 \mathrm{~m}$ in a few years' time (DETYA, 1999:Table 2.12). Say that the increase in Treasury receipts were $\$ 500 \mathrm{~m}$, due to the changes made in 1996 . Assuming that these payments were reflected in lower tax collections elsewhere, then a net economic advantage occurs if the excess burden of the taxes saved elsewhere exceeds the excess burden of this form of time-limited, graduate tax. The gains or losses in economic efficiency are those related to a switch in tax mix.

Since the rate of HECS debt repayment depends on the debtor's annual taxable income, then it seems reasonable to assume that it has the same excess burden as would a synthetic income tax at rates equal to the sum of the ordinary income tax rate, the Medicare levy and the HECS repayments. That is to say, this kind of increase in the tuition charge should be evaluated as though it were a selective addition to the income tax schedule for the graduates. Those with income above about $\$ 22,000$ re-pay any HECS debts at a rate set as a proportion of income, in addition to their ordinary income tax and Medicare levy. That is, for these income earners, their effective marginal 'tax' rate increases by from 3 to 6 per cent. In the absence of estimates of the effects of switching students into relatively cheaper courses, the source of economic gain or loss lies in the change in the efficiency of collection of public revenue.

There is a considerable controversy over estimates of the excess burden of taxation. For the US, Heckman (1999) has asserted that taxation of skill premia is close to a non-distorting, Henry George tax. Feldstein (1996) found the elasticity of income tax revenue collections much higher than the elasticity of work effort. Relevant also for public financial considerations is the argument made by Goulder and Williams (1999), that the usual partial-equilibrium approximations of excess burdens are far too low and can be improved.

\section{Conclusion}

It is the purpose of this article not to provide estimates, but to comment on the evidence that has been considered in policy circles, of rates of return to higher education; and to highlight the kind of evidence that should be considered, in making policy in higher education. Higher-education policy recommendations have been based on a combination of theory and rather-casual empiricism. The calculations most commonly cited in discussions of higher education policy are those of the private and social rates of return, usually derived from cross-sections 
of earnings by age and education. The private and social rates are averages, not marginals.

In the absence of additional information, neither the private nor the social rate of return to investment in education provides information that is of much direct relevance to policy-making. They are not 'policy-specific'; that is, they do not tell us the effects of a specific policy change. Rather, they reflect the endogenous responses of students and other decision-makers to the totality of past policy settings, as well as to numerous influences in the economy usually considered outside the realm of higher education policy. The 'Treasury' rate of return to its higher education spending does have the virtue of being calculated with respect to a policy variable (ie, public sector outlays) but is hopelessly flawed as a policy indicator, being an average rate of return, and only interpretable if we know the effect on higher education investments, of changes in the Treasury subsidy. However, the data required for the calculation of rates of return can be used, via formulae commonly applied in the public finance literature, to estimate the change in the excess burden of public revenue, which was a variable of policy-relevance during the last decade.

\section{References}

Andrews, L. (1999), 'Does HECS Deter: Factors Affection University Participation by Low SES Groups', Department of Employment, Education and Training (DETYA Occasional Paper 99-F).

Ashenfelter, O. and C. Rouse (1999), 'Schooling, Intelligence, and Income in America: Cracks in the Bell Curve', National Bureau of Economic Research (NBER Working Paper No. W6902).

Borland, J., P. Dawkins, D. Johnson and R. Williams (2000), 'Returns to Investment in Higher Education', Melbourne University (The Melbourne Economics of Higher Education Research Program Report No. 1)

Butlin, N. (1975), 'Salary Structures of Career Professionals', Department of Economic History, Research School of Social Sciences, Australian National University (photocopied seminar paper dated 20 June).

Blaug, M. (1970), An Introduction to the Economics of Education, Penguin, London.

Chapman, B. (1997), 'Conceptual Issues and the Australian Experience with Income Contingent Charges for Higher Education', The Economic Joumal 107:738-51.

Clotfelter, C. (1996), Buying the Best: Cost Escalation in Elite Higher Education, Princeton University Press, Princeton.

Department of Education, Training and Youth Affairs (DETYA) (1999), Higher Education Report for the 2000 to 2002 Triennium.

(accessed at http://www.detya.gov.au/highered/he_report/2000_2002/2_4.pdf, on 9/3/00). 
Dockery A., K. Norris and T. Stromback (1998), 'The social return to apprenticeship training.' Australian Economic Review 31(1):37-46.

Ehrenberg, R. and R. Smith (1997), Modern Labor Economics: Theory and Public Policy, sixth edtion, Addison-Wesley, Reading, Mass.

Fane, G (1988), 'Unto Everyone That Hath Shall Be Given', pp. 137-64 in G. Hogbin (ed.), Wthering Heights: The State of Higher Education in Australia, Allen \& Unwin and Centre of Policy Studies, Sydney.

Feldsteil, M. (1996), 'How Big Should Government Be?', National Bureau of Economic Researcl (NBER Working Paper No. 5868).

Garratt,R. and J. Marshall (1994), 'Public Finance of Private Goods: The Case of College Education', Journal of Political Economy 102:566-82.

Goulder, L. and R. Williams (1999), 'The Usual Excess-Burden Approximation Doesn't Come Cose', National Bureau of Economic Research (NBER Working Paper No. 7034).

Harrisol, M. (1997), 'The Funding of Teaching Services in Higher Education', Appendix 15 in Review of Higher Education Financing and Policy (West Review), Learning for Life. A Polic? Discussion Paper, Department of Employment, Education, Training and Youth Affairs, Canberra.

Heckman, J. (1999), 'Policies to Foster Human Capital', National Bureau of Economic Researcr (NBER Working Paper No. 7288).

Heckma, J., L. Lochner and C. Taber (1999), 'General Equilibrium Cost Benefit Analysis of Eduction and Tax Policies', National Bureau of Economic Research (NBER Working Paper No. 6881).

Hope, J.and P. Miller (1988), 'Financing Tertiary Education: An Examination of the Issues', Australian Economic Review, Fourth Quarter:37 -57.

Industry Commission (1997), Submission to the Review of Higher Education Financing and Policy, Canberra.

Maani, S. (1997), Investing in Minds: The Economics of Higher Education in New Zealand, Institute of Policy Studies, Wellington.

Maglen,L. (1990), 'Challenging the Human Capital Orthodoxy: The Education-Productivity Link Reexamined', Economic Record 66:281-294.

Marginson, S. (1995), 'Markets in Education: A Theoretical Note,' Australian Journal of Education 39(3):294-312.

Miller, P. and J. Pincus (1998), 'Financing the Australian Unified National System of Higher Ecucation: An Efficiency Analysis', Journal of Higher Education Policy and Management 20(1):51- 63 .

Nationa Commission of Audit (1996), Report to the Commonwealth Government, AGPS, Canberra. 
Pincus, J. (1998), 'Is the Treasury Subsidising Australian Undergraduates? Or, Investing in Higher Education', Adelaide University (School of Economics Working Paper No. 98-15)

Quiggin, J. (1995), 'Should we Be Investing More in Education?', paper presented at NBEET/ANU Education Conference, Canberra (accessed on 20/3/00 at http://ecocomm.anu.edu.au/quiggin/Conference/Education_investment95.html).

Winston, G. (1996), 'The Economic Structure of Higher Education: Subsidies, CustomerInputs, and Hierarchy', Williams College (Williams Project on the Economics of Higher Education, Discussion Paper No. 40).

This paper arose from a joint project with Paul Miller, for whose comments on earlier drafts, and those of Veronica Cosgrove, Sue Richardson, Lee Hansen, and anonymous referees, I am grateful. 